\title{
Wet Seed Treatment with Peroxyacetic Acid for the Control of Bacterial Fruit Blotch and Other Seedborne Diseases of Watermelon
}

\author{
D. L. Hopkins and C. M. Thompson, University of Florida, Mid-Florida Research and Education Center, Apopka, \\ 32703; J. Hilgren, Ecolab Inc., St. Paul, MN 55118; and B. Lovic, Syngenta Seeds, Inc., Woodland, CA 95695
}

\begin{abstract}
Hopkins, D. L., Thompson, C. M., Hilgren, J., and Lovic, B. 2003. Wet seed treatment with peroxyacetic acid for the control of bacterial fruit blotch and other seedborne diseases of watermelon. Plant Dis. 87:1495-1499.

Prevention of seed transmission of Acidovorax avenae subsp. citrulli into the transplant house or field is the most effective control of bacterial fruit blotch of watermelon currently available. Peroxyacetic acid was evaluated as a disinfectant that might efficaciously eradicate A. avenae subsp. citrulli from contaminated seed and also be efficacious against other seed-transmitted diseases of watermelon. Peroxyacetic acid at low concentrations eliminated A. avenae subsp. citrulli, Fusarium oxysporum, and Didymella bryoniae from microbial suspensions. Treatments of seed contaminated with $A$. avenae subsp. citrulli and $D$. bryoniae with peroxyacetic acid at $1,600 \mu \mathrm{g} / \mathrm{ml}$ and higher for $30 \mathrm{~min}$ were effective in preventing seed transmission of bacterial fruit blotch and gummy stem blight. Hydrochloric acid treatments at $10,000 \mu \mathrm{g} / \mathrm{ml}$, while effective in eliminating seed transmission to watermelon seedlings, can adversely affect seed germination, especially with triploid seed. Efficacious dosages of peroxyacetic acid can be applied safely to freshly harvested triploid watermelon seed without concerns for reduction in seed quality. A most effective wet seed treatment protocol involved a 30-min treatment with peroxyacetic acid at $1,600 \mu \mathrm{g} / \mathrm{ml}$ followed by seed drying at low humidity in a $40^{\circ} \mathrm{C}$ drying oven for $48 \mathrm{~h}$
\end{abstract}

Bacterial fruit blotch (BFB) of watermelon ( Citrullus lanatus), caused by Acidovorax avenae subsp. citrulli (formerly Pseudomonas pseudoalcaligenes subsp. citrulli), was first observed in commercial production areas in the United States in the spring of 1989 (11,15), causing losses of more than $90 \%$ of the marketable fruit in some fields. BFB of watermelon has occurred in one or more watermelon-producing states in the United States every year since 1989 (13). A severe epidemic developed throughout the eastern United States in 1994, where thousands of hectares of watermelon in at least 10 states were affected (5).

The causal agent of BFB can be seedborne in watermelon $(8,14,17)$. Contamination of watermelon seedlots is one way in which the bacterium may be introduced into a watermelon field or transplant house, where, under favorable environmental conditions, it can spread rapidly throughout the greenhouse (12) or field (4). Because of the pending lawsuits and the risk of

Corresponding author: D. L. Hopkins

E-mail: dlhopkins@mail.ifas.ufl.edu

Florida Agricultural Experiment Station Journal Series No. R-09192

Accepted for publication 30 July 2003.

Publication no. D-2003-1007-03R

(C) 2003 The American Phytopathological Society future litigation, the sale of seed in the United States was suspended temporarily in the fall of 1994 by most of the major watermelon seed companies, thus threatening the very existence of a watermelon industry in 1995 (10).

The most effective control of BFB of watermelon currently available is the exclusion of the bacterium from the field (9). The intensive efforts of the watermelon seed industry and the transplant industry to produce seed and transplants free of $A$. avenae subsp. citrulli have reduced the incidence of BFB significantly over the last five to six seasons (D. L. Hopkins, unpublished). These efforts include improved production practices by the seed producer, fermentation and acid treatment of diploid seed (5), use of seed from seed lots that have assayed negative for the presence of A. avenae subsp. citrulli by grow-out of at least 10,000 seedlings or polymerase chain reaction assay (16), and careful inspection of seedlings for symptoms by the transplant producer. In spite of these efforts, the bacterium still appears in a few fields every year. Currently, the only control option for fruit blotch once it gets into a field is multiple applications of a copper-containing bactericide/fungicide (3).

Although fermentation and hydrochloric acid $(\mathrm{HCl})$ treatments are effective in removing the bacterium from seed, they can, in some cases, adversely affect seed quality. Thus, there is still a need for disinfectants that can efficaciously eradicate seed- borne contaminants at the time of seed harvest and not reduce any measurable parameters of seed quality. Characteristics of peroxyacetic acid (PA) as a disinfectant indicate that it may be suitable for the elimination of $A$. avenae subsp. citrulli from contaminated watermelon seed (1). The objectives of this study were to evaluate the efficacy of PA as a disinfectant for the elimination of A. avenae subsp. citrulli from contaminated watermelon seed, to assess the significance of source of inoculum and seed drying conditions on the efficacy of disinfectants, and to evaluate the efficacy of PA against seed-transmitted Fusarium oxysporum and Didymella bryoniae.

\section{MATERIALS AND METHODS}

Pathogens. A strain of A. avenae subsp. citrulli (WFB89-1) isolated in 1989 in Florida from a commercial watermelon cultivar was used throughout these tests. WFB89-1 was stored at $-70^{\circ} \mathrm{C}$ in nutrient broth or glycerol and was grown on nutrient agar for preparation of inoculum. This strain has given reproducible, severe symptoms on commercial varieties (7). An $F$. oxysporum strain (Fo96-3) originally isolated from wilted watermelon on the Leesburg research center in 1996 was used in the suspension culture experiments. A gummy stem blight (GSB) isolate 98-2B, also obtained from watermelon on the Leesburg research center in 1998, was used throughout these studies.

Suspension culture experiments. The rate at which PA killed the plant-pathogenic microorganisms was measured by inoculating use-solutions of each antimicrobial agent and then quantifying survivors after various exposure times. For these tests, WFB89-1 was grown on nutrient agar for $48 \mathrm{~h}$ and washed from the agar surface with sterile, deionized water. The bacterial suspension was adjusted to absorbance at $600 \mathrm{~nm}\left(A_{600 \mathrm{~nm}}\right)=0.25$ with a spectrophotometer $\left(10^{6}\right.$ to $\left.10^{7} \mathrm{CFU} / \mathrm{ml}\right)$. Conidial suspensions of Fo96-3 were prepared from 5-day-old liquid cultures in potato dextrose broth. Spores were collected by centrifugation and resuspended in water to a concentration of $10^{5}$ conidia $/ \mathrm{ml}$ as determined with a hemacytometer. GSB98-2B was grown on V8 juice agar for 3 weeks and spores were washed from the agar surface with sterile water. The concentration was adjusted to $10^{5}$ spores $/ \mathrm{ml}$ using the hemacytometer to count spores. 
For the suspension culture tests, disinfectant solutions included PA at 8,80 , and $800 \mu \mathrm{g} / \mathrm{ml}$ and $\mathrm{HCl}$ at $8,80,800,1,000$, and $10,000 \mu \mathrm{g} / \mathrm{ml}$. The test solution $(49.5$ $\mathrm{ml})$ was transferred to a flask and allowed to equilibrate to $25^{\circ} \mathrm{C}$. The liquid in the flask was swirled vigorously in a rapid circular motion and $0.5 \mathrm{ml}$ of a microbial suspension was added. After $30 \mathrm{~s}$ and 2, 5, and $10 \mathrm{~min}, 1-\mathrm{ml}$ quantities of the disinfectant-microbial solution were transferred to dium thiosulfate that inactivated PA. Aliquots and dilutions consisting of $0.1 \mathrm{ml}$ of inactivating solution were spread-plated onto the appropriate agar media. In the case of A. avenae subsp. citrulli, $0.1 \mathrm{ml}$ of inactivating solution and $0.1 \mathrm{ml}$ of a 100fold dilution were spread-plated onto a diagnostic medium (2). This diagnostic media consisted of peptone (5 g/liter), $\mathrm{CaCl}_{2} \quad(0.25 \mathrm{~g} / \mathrm{liter})$, Tween $80 \quad(10$ $\mathrm{ml} / \mathrm{liter}$ ), and agar (15 g/liter). Cycloheximide (50 $\mathrm{mg} / \mathrm{liter})$ and carbenicillin (50 mg/liter) were added after autoclaving. $9 \mathrm{ml}$ of a solution consisting of $0.1 \%$ so-

With $F$. oxysporum, 0.1-ml aliquots of inactivating solution were spread-plated onto potato-dextrose agar. With $D$. bryoniae, $0.1-\mathrm{ml}$ aliquots of inactivating solution were spread-plated onto V8 agar.

Production of seed contaminated with $A$. avenae subsp. citrulli and $D$. bryoniae. Contaminated seed for the first evaluation of PA concentrations and length of seed treatment (Table 1) were produced in the spring of 1999. 'Crimson Sweet' watermelon plants were grown on the research farm at Leesburg and were naturally infected with BFB and GSB. Using a commercial seed harvester, seed were collected from mostly symptomless fruit, although there were some BFB symptoms on a few fruit. After removal of the watermelon pulp, the seed were mixed back into watermelon juice. To assure seed contamination, A. avenae subsp. citrulli was added to the suspension of seed in watermelon juice diluted with water to give a bacterial concentration of $10^{5}$ to $10^{6} \mathrm{CFU} / \mathrm{ml}$. D. bryoniae was added to a seed suspension at a

Table 1. Effect of peroxyacetic acid concentration and duration of seed treatment on seed transmission of bacterial fruit blotch (BFB) and gummy stem blight (GSB) of watermelon

\begin{tabular}{lccccc}
\hline Treatment & $\begin{array}{c}\text { Concentration } \\
(\boldsymbol{\mu g} / \mathbf{m l})\end{array}$ & $\begin{array}{c}\text { Exposure } \\
\text { time (min) }\end{array}$ & $\begin{array}{c}\text { Germination } \\
(\boldsymbol{\%})^{\mathbf{z}}\end{array}$ & ${\text { BFB }(\boldsymbol{\%})^{\mathbf{z}}}^{\mathbf{y}}$ & ${\mathbf{G S B}(\boldsymbol{\%})^{\mathbf{z}}}^{\mathbf{z}}$ \\
\hline Untreated & $\ldots$ & 15 & $97 \mathrm{a}$ & $42 \mathrm{a}$ & $13 \mathrm{a}$ \\
Peroxyacetic acid & 1,800 & 15 & $96 \mathrm{a}$ & $0 \mathrm{~b}$ & $2 \mathrm{bc}$ \\
Peroxyacetic acid & 5,600 & 15 & $96 \mathrm{a}$ & $0 \mathrm{~b}$ & $0 \mathrm{c}$ \\
Peroxyacetic acid & 16,800 & 15 & $99 \mathrm{a}$ & $0 \mathrm{~b}$ & $0 \mathrm{c}$ \\
Hydrochloric acid & 10,000 & 15 & $97 \mathrm{a}$ & $0 \mathrm{~b}$ & $2 \mathrm{bc}$ \\
Untreated & $\ldots$ & 30 & $92 \mathrm{a}$ & $44 \mathrm{a}$ & $15 \mathrm{a}$ \\
Peroxyacetic acid & 1,800 & 30 & $97 \mathrm{a}$ & $0 \mathrm{~b}$ & $0 \mathrm{c}$ \\
Peroxyacetic acid & 5,600 & 30 & $98 \mathrm{a}$ & $0 \mathrm{~b}$ & $0 \mathrm{c}$ \\
Peroxyacetic acid & 16,800 & 30 & $98 \mathrm{a}$ & $0 \mathrm{~b}$ & $0 \mathrm{c}$ \\
Hydrochloric acid & 10,000 & 30 & $94 \mathrm{a}$ & $0 \mathrm{~b}$ & $5 \mathrm{~b}$ \\
\hline
\end{tabular}

$y$ BFB- and GSB-contaminated seed were treated with the peroxyacetic acid or hydrochloric acid solutions in 5-liter buckets, with stirring. After treatment, seed were collected on wire screens and dried for $48 \mathrm{~h}$ on a greenhouse bench at 25 to $35^{\circ} \mathrm{C}$.

${ }^{\mathrm{z}}$ Values are the means of four replications of 200 seed each. Means followed by different letters within a column are significantly different by Duncan's new multiple range test, $P=0.05$ level. The percent seed transmission of BFB was determined by a greenhouse grow-out of the seedlings and is the percentage of seedlings (germinated seed) that were symptomatic.

Table 2. Effect of peroxyacetic acid concentration and duration of seed treatment on seed transmission of bacterial fruit blotch (BFB) of watermelon and cantaloupe

\begin{tabular}{|c|c|c|c|c|c|c|}
\hline \multirow[b]{2}{*}{ Treatment $^{\mathrm{z}}$} & \multirow[b]{2}{*}{$\begin{array}{c}\text { Concentration } \\
(\mu \mathrm{g} / \mathrm{ml})\end{array}$} & \multirow[b]{2}{*}{$\begin{array}{l}\text { Exposure } \\
\text { time (min) }\end{array}$} & \multicolumn{2}{|c|}{ Watermelon test ${ }^{y}$} & \multicolumn{2}{|c|}{ Cantaloupe test $\mathrm{y}^{\mathrm{y}}$} \\
\hline & & & $\begin{array}{c}\text { Germ. } \\
(\%)\end{array}$ & $\begin{array}{c}\text { BFB } \\
(\%)\end{array}$ & $\begin{array}{c}\text { Germ. } \\
(\%)\end{array}$ & $\begin{array}{c}\text { BFB } \\
(\%)\end{array}$ \\
\hline Untreated & & 15 & $90 \mathrm{a}$ & $1.0 \mathrm{~b}$ & $87 \mathrm{a}$ & $3.0 \mathrm{a}$ \\
\hline PA & 1,800 & 15 & $92 \mathrm{a}$ & $0.3 \mathrm{bc}$ & $87 \mathrm{a}$ & $0 \mathrm{c}$ \\
\hline $\mathrm{PA}$ & 1,200 & 15 & $93 \mathrm{a}$ & $0.3 \mathrm{bc}$ & $86 \mathrm{a}$ & $0.3 \mathrm{bc}$ \\
\hline PA & 900 & 15 & $87 \mathrm{ab}$ & $0.3 \mathrm{bc}$ & $81 \mathrm{a}$ & $0.3 \mathrm{bc}$ \\
\hline $\mathrm{HCl}$ & 10,000 & 15 & $81 \mathrm{~b}$ & $0 \mathrm{c}$ & $70 \mathrm{~b}$ & $0 \mathrm{c}$ \\
\hline Untreated & & 30 & $91 \mathrm{a}$ & $3.0 \mathrm{a}$ & $85 \mathrm{a}$ & $1 \mathrm{~b}$ \\
\hline PA & 1,800 & 30 & $92 \mathrm{a}$ & $0 \mathrm{c}$ & $87 \mathrm{a}$ & $0 \mathrm{c}$ \\
\hline $\mathrm{PA}$ & 1,200 & 30 & $92 \mathrm{a}$ & $0.5 \mathrm{bc}$ & $88 \mathrm{a}$ & $0 \mathrm{c}$ \\
\hline PA & 900 & 30 & $92 \mathrm{a}$ & $0.3 \mathrm{bc}$ & $86 \mathrm{a}$ & $0.3 \mathrm{bc}$ \\
\hline $\mathrm{HCl}$ & 10,000 & 30 & $68 \mathrm{c}$ & $0 \mathrm{c}$ & $82 \mathrm{a}$ & $0 \mathrm{c}$ \\
\hline
\end{tabular}

${ }^{\mathrm{y}}$ Germ. $=$ germination. Values are the means of four replications of 100 seed each. Means followed by different letters within a column are significantly different by Duncan's new multiple range test, $P=0.05$ level. The percent seed transmission of BFB was determined by a greenhouse grow-out of the seedlings and is the percentage of seedlings (germinated seed) that were symptomatic.

${ }^{\mathrm{z}}$ BFB-contaminated seed were treated with the peroxyacetic acid (PA) or hydrochloric acid $(\mathrm{HCl})$ solutions in 5-liter buckets, with stirring. After treatment, seed were collected on wire screens and dried for $48 \mathrm{~h}$ on a greenhouse bench at 25 to $35^{\circ} \mathrm{C}$. concentration of $3.6 \times 10^{6} \mathrm{conidia} / \mathrm{ml}$. The seed were incubated in the bacteria or spore suspension for $2 \mathrm{~h}$ with mixing every $30 \mathrm{~min}$. After treatment, seed were rinsed briefly and separated for treatments, based on visual estimation of seed volume. A grow-out of the Crimson Sweet seed not incubated with bacteria or spores demonstrated that the seed were "naturally" infected with seed-transmissible BFB and GSB; therefore, these seed were both naturally contaminated and inoculated.

Seed for the second evaluations of PA concentrations and length of seed treatment (Table 2) were produced in the spring of 2000. 'Charleston Gray' watermelon plants were grown on the research farm at Leesburg and were naturally infected with BFB. Seed were collected by hand from fruit with symptoms, and symptomatic rind tissue was added to the watermelon juice slurry. BFB-free 'Saticoy' cantaloupe seed also were grown and collected by hand. Seed were inoculated with A. avenae subsp. citrulli as described above for watermelon in 1999. Watermelon seed were naturally contaminated and inoculated; cantaloupe seed were inoculated with $A$. avenae subsp. citrulli.

For the evaluation of the effect of seed drying conditions on treatment with PA, 'Sangria' watermelon fruit free of BFB were obtained from a commercial farm in November 2000. Seed were collected by hand and inoculated as described above. These seed were inoculated after harvest.

Wet seed treatment efficacy tests. Multiple experiments were conducted over 3 years to test efficacy of PA-based disinfectant Tsunami 100 (15\% PA and $11 \%$ hydrogen peroxide; Ecolab Inc., Mendota Heights, MN). Seed were treated with disinfectant treatments within $1 \mathrm{~h}$ of the completion of contamination with A. avenae subsp. citrulli or D. bryoniae. Disinfectant treatments were conducted in 5-liter plastic buckets on the greenhouse bench. Seed were covered with approximately 1.5 liters of disinfectant solution. The solutions were stirred periodically throughout the treatments. After treatment, seed either were rinsed gently in a volume of tap water equal to that of the seed or not rinsed at all.

PA efficacy against seed transmission of BFB and GSB as a wet seed treatment was evaluated at concentrations ranging from 1,800 to $16,800 \mu \mathrm{g} / \mathrm{ml}$ with treatment exposure times of 15 and $30 \mathrm{~min}$ and was compared with $\mathrm{HCl}$ at $10,000 \mu \mathrm{g} / \mathrm{ml}(1 \%)$. Concentrations of PA and $\mathrm{HCl}$ in the treatments were calculated from the concentration of active ingredients in Tsunami 100 and concentrated $\mathrm{HCl}$ on a wt/vol basis. After treatment, seed were dried on screens on the greenhouse bench for $48 \mathrm{~h}$ at temperatures ranging from $26^{\circ} \mathrm{C}$ at night to $40^{\circ} \mathrm{C}$ in the afternoon. PA concentrations ranging from 900 to $1,800 \mu \mathrm{g} / \mathrm{ml}$ were evaluated for effect on seed transmission of BFB in Charleston Gray watermelon seed 
and Saticoy cantaloupe seed treated for 15 and $30 \mathrm{~min}$.

Thirty-minute treatments of contaminated Sangria seed with PA at 320 and $1,600 \mu \mathrm{g} / \mathrm{ml}$ were used in studies comparing the effect of different drying conditions on efficacy of the disinfectant. The 48-h drying conditions were (i) greenhouse bench, where temperatures ranged from $24^{\circ} \mathrm{C}$ at night to $35^{\circ} \mathrm{C}$ in the afternoon; (ii) $40^{\circ} \mathrm{C}$ drying oven; (iii) $30^{\circ} \mathrm{C}$ drying oven; and (iv) $25^{\circ} \mathrm{C}$ drying oven for $24 \mathrm{~h}$ and a greenhouse bench for $24 \mathrm{~h}$.

For the greenhouse assay of seed transmission of BFB or GSB to seedlings, seed were planted in 28-by-52-cm plastic trays filled with commercial potting mix. Two rows of 25 seed were planted in each tray. In the PA rate and treatment exposure time tests with Charleston Gray watermelon and Saticoy cantaloupe, four replications of 100 seed each were planted; all other tests consisted of four replications of 200 seed. When plants emerged, the seedling trays in a treatment replication were covered with plastic domes for two nights. Seedling trays were watered carefully on the surface of the potting mix with a hose, avoiding contact with the seedlings. Greenhouse temperatures ranged from 24 to $40^{\circ} \mathrm{C}$. Disease incidence evaluations were made 10 days after planting. Percent seed transmission was calculated based on the number of emerged seedlings.

Seed safety evaluations. Triploid watermelon seed (cv. Tri-X-313), free of $\mathrm{BFB}$, were used in this test because they are known to be most sensitive to disinfectants. Approximately $300 \mathrm{~g}$ of freshly harvested seed per treatment were submerged in mesh bags in disinfectant solution at room temperature for 15 min with periodic agitation. PA was evaluated at 3,200 , 6,400 , and $9,600 \mu \mathrm{g} / \mathrm{ml}$ and $\mathrm{HCl}$ was evaluated at $10,000 \mu \mathrm{g} / \mathrm{ml}$. Following exposure to the disinfectants, seed ether were rinsed in a stream of tap water for 5 min or immediately placed to dry. Seed were air dried in a stationary seed dryer. Germination was assessed by planting eight replications of 50 seed each into greenhouse substrate (Sunshine Mix \#1) and counting the number of seedlings after 14 days. For dry weight determinations, seedlings were cut off at the base, placed in paper bags, dried in a convection oven for 4 days at $60^{\circ} \mathrm{C}$, and weighed.

\section{RESULTS}

Suspension culture experiments. All three seedborne pathogens of watermelon that were evaluated were sensitive to PA at $80 \mu \mathrm{g} / \mathrm{ml}$. PA at $80 \mu \mathrm{g} / \mathrm{ml}$ eliminated $A$. avenae subsp. citrulli from water suspensions in less then $30 \mathrm{~s}$ (Table 3). Approximately a 10-fold higher concentration of $\mathrm{HCl}$ achieved a similar level of efficacy. The fungal pathogens $D$. bryoniae and $F$. oxysporum were less sensitive to both PA and $\mathrm{HCl}$ than was A. avenae subsp. citrulli.
PA at $80 \mu \mathrm{g} / \mathrm{ml}$ eliminated D. bryoniae from suspensions in less than 2 min of exposure and $F$. oxysporum in less than 5 min; whereas $\mathrm{HCl}$ at 800 or $1,000 \mu \mathrm{g} / \mathrm{ml}$ did not kill either fungus with $10 \mathrm{~min}$ of exposure. $\mathrm{HCl}$ at $10,000 \mu \mathrm{g} / \mathrm{ml}$ did eliminate both fungi from suspensions.

Wet seed treatment efficacy tests. PA treatments at concentrations of $1,800 \mu \mathrm{g} / \mathrm{ml}$ and higher for 15 or $30 \mathrm{~min}$ completely eliminated seed transmission of BFB in contaminated watermelon seed without affecting seed viability (Table 1). There was 42 and $44 \%$ transmission of BFB to seedlings in the untreated seed. $\mathrm{HCl}$ treatment at $10,000 \mu \mathrm{g} / \mathrm{ml}(1 \%)$ also prevented seed transmission of BFB without affecting seed viability. Seed transmission of GSB was completely eliminated by a 30-min treatment with PA at $1,800 \mu \mathrm{g} / \mathrm{ml}$, but not by the 15 -min treatment (Table 1). After 15 or $30 \mathrm{~min}$ of exposure of seed to $\mathrm{HCl}$ at $10,000 \mu \mathrm{g} / \mathrm{ml}$, seed transmission of GSB was reduced but not eliminated. There was 13 and $15 \%$ seed transmission of GSB in untreated seed.

With contaminated Charleston Gray watermelon seed, PA concentrations of 1,200 and $900 \mu \mathrm{g} / \mathrm{ml}$ reduced the seed transmission of $\mathrm{BFB}$ to $<1 \%$ ( 1 or 2 seed transmissions per 400 seed), but did not eliminate it (Table 2). This seed lot had a relatively low seed transmission rate in the untreated seed of 1 and 3\%. A 30-min treatment with PA at $1,800 \mu \mathrm{g} / \mathrm{ml}$ eliminated seed transmission of BFB but a 15-min treatment did not. $\mathrm{HCl}$ was effective, but reduced seed germination in the 30-min treatment. In a seedlot of Saticoy cantaloupe with 3 and $1 \%$ seed transmission of BFB in the un- treated seed, PA at $1,800 \mu \mathrm{g} / \mathrm{ml}$ for 15 or $30 \mathrm{~min}$ of exposure and at $1,200 \mu \mathrm{g} / \mathrm{ml}$ for 30 min completely eliminated seed transmission of BFB (Table 2). At $900 \mu \mathrm{g} / \mathrm{ml}$, PA reduced but did not eliminate seed transmission in cantaloupe. $\mathrm{HCl}$ at 10,000 $\mu \mathrm{g} / \mathrm{ml}$ eliminated seed transmission, but appeared to reduce germination in the 15 min treatment.

The incidence of seed-transmissible BFB was different after aliquots from the same batch of nondisinfected seed were dried under different conditions (Table 4). Seed dried in the drying oven at $40^{\circ} \mathrm{C}$ or in the $25^{\circ} \mathrm{C}$ drying oven for $24 \mathrm{~h}$ and a greenhouse bench for $24 \mathrm{~h}$ yielded a significantly higher level of seed-transmissible BFB compared with seed dried in the $30^{\circ} \mathrm{C}$ drying oven or on the greenhouse bench, where temperatures ranged from $24^{\circ} \mathrm{C}$ at night to $35^{\circ} \mathrm{C}$ in the afternoon. However, when these contaminated seed were disinfected with PA at $1,600 \mu \mathrm{g} / \mathrm{ml}$ and dried under the same four conditions, only seed that were dried in the drying oven at $40^{\circ} \mathrm{C}$ had no seed transmission of BFB in either test (Table 4). Seed transmission was observed in only one of the two tests with seed dried in the $30^{\circ} \mathrm{C}$ drying oven or on the greenhouse bench. PA at $320 \mu \mathrm{g} / \mathrm{ml} \mathrm{did}$ not eliminate seed transmission under any of the drying conditions.

Seed safety evaluations. Exposure to 15-min treatments of PA at concentrations of 3,200 and $6,400 \mu \mathrm{g} / \mathrm{ml}$ did not significantly reduce either germination or vigor (seedling weight) of triploid watermelon seed even if the seed were not rinsed after the treatment (Table 5). PA at 9,600 $\mu \mathrm{g} / \mathrm{ml}$ and $\mathrm{HCl}$ at $10,000 \mu \mathrm{g} / \mathrm{ml}$ did not affect

Table 3. Rate of kill of seedborne watermelon pathogens in water suspension cultures by hydrochloric acid $(\mathrm{HCl})$ and peroxyacetic acid $(\mathrm{PA})$

\begin{tabular}{|c|c|c|c|c|c|}
\hline \multirow[b]{2}{*}{ Treatment $^{\mathrm{z}}$} & \multirow[b]{2}{*}{ Concentration $(\mu \mathrm{g} / \mathrm{ml})$} & \multicolumn{4}{|c|}{ No. of surviving pathogens ${ }^{y}$} \\
\hline & & 0.5 & 2.0 & 5.0 & 10.0 \\
\hline \multicolumn{6}{|l|}{$\begin{array}{l}\text { Acidovorax avenae } \\
\text { subsp. citrulli }\end{array}$} \\
\hline Untreated & & $>10^{3}$ & $>10^{3}$ & $>10^{3}$ & $>10^{3}$ \\
\hline $\mathrm{HCl}$ & 10,000 & ND & ND & ND & ND \\
\hline $\mathrm{HCl}$ & 800 & ND & ND & ND & ND \\
\hline $\mathrm{HCl}$ & 80 & $>10^{3}$ & $>10^{3}$ & $>10^{3}$ & $>10^{3}$ \\
\hline Peroxyacetic acid & 80 & ND & ND & ND & ND \\
\hline Peroxyacetic acid & 8 & $>10^{3}$ & $>10^{3}$ & 29 & ND \\
\hline \multicolumn{6}{|l|}{ Didymella bryoniae } \\
\hline Untreated & & 4 & 4 & 5 & 6 \\
\hline $\mathrm{HCl}$ & 10,000 & ND & ND & ND & ND \\
\hline $\mathrm{HCl}$ & 1,000 & 6 & 6 & 5 & 5 \\
\hline PA & 800 & ND & ND & ND & ND \\
\hline PA & 80 & 2 & ND & ND & ND \\
\hline \multicolumn{6}{|c|}{ Fusarium oxysporum } \\
\hline Untreated & $\ldots$ & $>100$ & $>100$ & $>100$ & $>100$ \\
\hline PA & 80 & $>100$ & 20 & ND & ND \\
\hline $\mathrm{HCl}$ & 10,000 & ND & ND & ND & ND \\
\hline $\mathrm{HCl}$ & 800 & $>100$ & $>100$ & $>100$ & $>100$ \\
\hline
\end{tabular}

${ }^{y}$ Surviving pathogen populations per $0.01 \mathrm{ml}$ of disinfectant-microbial solution after exposure to the treatments for $0.5,2.0,5.0$, or $10.0 \mathrm{~min} . \mathrm{ND}=$ not detectable.

${ }^{\mathrm{z}}$ Microbial suspensions $(0.5 \mathrm{ml})$ were added to $49.5 \mathrm{ml}$ of the treatment solutions at $25^{\circ} \mathrm{C}$. The liquids in the flask were swirled vigorously in a rapid circular motion. After $30 \mathrm{~s}, 2,5$, and $10 \mathrm{~min}-$ utes, $1 \mathrm{ml}$ quantities of the treatments were transferred to $9 \mathrm{ml}$ of a $0.1 \%$ sodium thiosulfate solution to deactivate peroxyacetic acid. Aliquots and dilutions consisting of $0.1 \mathrm{ml}$ of disinfectant/microbial solutions were spread-plated onto the appropriate agar media. 
germination or vigor if the seed were rinsed, but reduced germination and seed-

\section{DISCUSSION}

There are two functions that a seed disinfectant has to perform in order to satisfy the requirements for application to freshly harvested seed of cucurbit crops. The first function is to inactivate pathogens which are present in the solution containing the seed to prevent cross contamination of seed. The second is to eradicate pathogens which are already established on or in the seed. PA was most effective in the first function, eliminating A. avenae subsp. citrulli from suspensions when used at very low concentrations. PA also appears to be effective at low concentrations in suspensions against other seedborne cucurbit pathogens, including fungi such as $D$. ling vigor if there was no seed rinsing.

bryoniae and $F$. oxysporum. Approximately 10 - to 100 -fold higher concentrations of $\mathrm{HCl}$ were needed to achieve similar levels of efficacy.

In this study, PA disinfectant treatments of seed contaminated with A. avenae subsp. citrulli and D. bryoniae was effective in preventing seed transmission of BFB and GSB to watermelon seedlings. Treatment concentrations of $1,600 \mu \mathrm{g} / \mathrm{ml}$ and higher with $30 \mathrm{~min}$ of exposure of the seed to disinfectant were most effective. In previous studies, calcium hypochlorite and sodium hypochlorite were relatively ineffective as wet seed treatments to prevent seed transmission of $\mathrm{BFB}$ to watermelon seedlings, but $\mathrm{HCl}$ at $10,000 \mu \mathrm{g} / \mathrm{ml}$ was efficacious $(5,14)$. In this study, the PA at $1,600 \mu \mathrm{g} / \mathrm{ml}$ treatment was as effective against $\mathrm{BFB}$ as was the $\mathrm{HCl}$ at 10,000 $\mu \mathrm{g} / \mathrm{ml}$ treatment. Seed transmission of $A$.

Table 4. Effect of seed drying temperature and peroxyacetic acid wet seed treatment on seed transmission of bacterial fruit blotch (BFB) of watermelon

\begin{tabular}{|c|c|c|c|c|c|}
\hline \multirow[b]{2}{*}{ Treatment $^{\mathbf{y}}$} & \multirow[b]{2}{*}{$\operatorname{Temp}\left({ }^{\circ} \mathbf{C}\right)^{\mathrm{z}}$} & \multicolumn{2}{|c|}{ Test $1^{x}$} & \multicolumn{2}{|c|}{ Test $2^{x}$} \\
\hline & & Germination (\%) & BFB (\%) & Germination (\%) & BFB $(\%)$ \\
\hline Untreated & $\mathrm{GH}$ & $91 \mathrm{bc}$ & $47 \mathrm{~b}$ & $96 a$ & $68 \mathrm{~b}$ \\
\hline $320 \mu \mathrm{g} / \mathrm{ml}$ & $\mathrm{GH}$ & $94 \mathrm{ab}$ & $2 \mathrm{c}$ & 98 a & $1 \mathrm{~d}$ \\
\hline $1600 \mu \mathrm{g} / \mathrm{ml}$ & $\mathrm{GH}$ & 96 a & $0 \mathrm{c}$ & $99 a$ & $1 \mathrm{~d}$ \\
\hline Untreated & 40 & $86 \mathrm{c}$ & $85 \mathrm{a}$ & $94 \mathrm{a}$ & $86 \mathrm{a}$ \\
\hline $320 \mu \mathrm{g} / \mathrm{ml}$ & 40 & $95 a b$ & $0.5 \mathrm{c}$ & 99 a & $4 \mathrm{c}$ \\
\hline $1600 \mu \mathrm{g} / \mathrm{ml}$ & 40 & $94 \mathrm{ab}$ & $0 \mathrm{c}$ & $98 \mathrm{a}$ & $0 \mathrm{~d}$ \\
\hline Untreated & 30 & $93 a b$ & $48 \mathrm{~b}$ & $99 \mathrm{a}$ & $66 \mathrm{~b}$ \\
\hline $320 \mu \mathrm{g} / \mathrm{ml}$ & 30 & $96 \mathrm{a}$ & $2 \mathrm{c}$ & $100 \mathrm{a}$ & $3 c$ \\
\hline $1600 \mu \mathrm{g} / \mathrm{ml}$ & 30 & $97 \mathrm{a}$ & $0.3 \mathrm{c}$ & $99 \mathrm{a}$ & $0 \mathrm{~d}$ \\
\hline Untreated & 25 & $86 \mathrm{c}$ & $80 \mathrm{a}$ & $97 \mathrm{a}$ & $90 \mathrm{a}$ \\
\hline $320 \mu \mathrm{g} / \mathrm{ml}$ & 25 & $96 \mathrm{a}$ & $2 \mathrm{c}$ & $97 \mathrm{a}$ & $4 \mathrm{c}$ \\
\hline $1600 \mu \mathrm{g} / \mathrm{ml}$ & 25 & $96 \mathrm{a}$ & $0.8 \mathrm{c}$ & $98 \mathrm{a}$ & $0.3 \mathrm{~d}$ \\
\hline
\end{tabular}

$\mathrm{x}$ Values are the means of four replications of 200 seed each. Means followed by different letters within a column are significantly different by Duncan's new multiple range test, $P=0.05$ level. The percent seed transmission of BFB was determined by a greenhouse grow out of the seedlings and is the percentage of seedlings (germinated seed) that were symptomatic.

y BFB-contaminated seed were treated with the peroxyacetic acid solutions for $30 \mathrm{~min}$, with stirring.

${ }^{\mathrm{z}}$ Drying temperature. After treatment, seed were collected on wire screens and dried for $48 \mathrm{~h}$ on a greenhouse bench at 25 to $35^{\circ} \mathrm{C}(\mathrm{GH})$, or at 25,30 , or $40^{\circ} \mathrm{C}$.

Table 5. Effect of peroxyacetic acid $(\mathrm{PA})$ and hydrochloric acid $(\mathrm{HCl})$ on seed germination and seedling dry weight accumulation for triploid watermelon $\left(\mathrm{cv}\right.$. Tri-X-313) ${ }^{\mathrm{w}}$

\begin{tabular}{lcccc}
\hline Disinfectant & Concentration $(\boldsymbol{\mu g} / \mathbf{m l})$ & Rinsing $^{\mathbf{x}}$ & ${\text { Germination }(\%)^{\mathbf{y}}}$ & Seedling weight $(\mathbf{g})^{\mathbf{z}}$ \\
\hline PA & 3,200 & Yes & $99 \mathrm{a}$ & $5.80 \mathrm{a}$ \\
PA & 3,200 & No & $97 \mathrm{a}$ & $5.15 \mathrm{a}$ \\
PA & 6,400 & Yes & $98 \mathrm{a}$ & $5.10 \mathrm{a}$ \\
PA & 6,400 & No & $97 \mathrm{a}$ & $4.95 \mathrm{a}$ \\
PA & 9,600 & Yes & $98 \mathrm{a}$ & $5.16 \mathrm{a}$ \\
PA & 9,600 & No & $69 \mathrm{~b}$ & $3.08 \mathrm{~b}$ \\
HCl & 10,000 & Yes & $98 \mathrm{a}$ & $5.13 \mathrm{a}$ \\
HCl & 10,000 & No & $4 \mathrm{c}$ & $0.12 \mathrm{c}$ \\
Water & $\cdots$ & Yes & $98 \mathrm{a}$ & $5.34 \mathrm{a}$ \\
Water & $\ldots$ & No & $95 \mathrm{a}$ & $5.20 \mathrm{a}$ \\
\hline
\end{tabular}

${ }^{\mathrm{w}}$ Approximately $300 \mathrm{~g}$ of freshly harvested seed (per treatment) contained in mesh bags were submerged in disinfectant solution at room temperature for $15 \mathrm{~min}$ with periodic agitation.

${ }^{x}$ Following exposure to the disinfectants, seed ether were rinsed in a stream of tap water for $5 \mathrm{~min}$ (Yes) or immediately placed to dry (No).

${ }^{y}$ Germination was assessed by planting eight replications of 50 seed each into greenhouse substrate (Sunshine Mix \#1) and evaluated number of seedlings after 14 days. Means followed by different letters within a column are significantly different by Duncan's new multiple range test, $P=0.05$ level.

${ }^{\mathrm{z}}$ Seedlings were cut off at the base, placed in paper bags, and dried in a convection oven for 4 days at $60^{\circ} \mathrm{C}$. Means followed by different letters within a column are significantly different by Duncan's new multiple range test, $P=0.05$ level. avenae subsp. citrulli was demonstrated in nine different cucurbits, even when there were no fruit symptoms, illustrating that all cucurbit crops must be included in the control strategies for BFB (6). Any cucurbit crop being grown in the same transplant house or field is a potential source of the bacterium for infection of watermelon or other cucurbits on which disease loss can occur, such as muskmelon and honeydew. In this study, PA was as effective, or more effective, in preventing seed transmission of BFB to cantaloupe seedlings as it was with watermelon. Thus, PA could be used to prevent seed transmission of $\mathrm{BFB}$ on various cucurbit crops.

The percent seed transmission of BFB in untreated "naturally" contaminated seed and untreated seed that was inoculated after harvest was very similar (Table 1 compared with Table 4). The lower seed transmission in the experiments in Table 2 seemed to be unrelated to method of seed contamination, because the watermelon seed were contaminated naturally and the cantaloupe seed were inoculated. Efficacy of PA in preventing seed-transmissible BFB was consistent in all experiments, suggesting that it was equally effective on naturally contaminated seed and on inoculated seed.

Seed drying temperatures affected both the amount of seed transmission of BFB in nondisinfected seed and the effectiveness of PA in eliminating seed transmission of BFB. However, due to the variation of other parameters (e.g., relative humidity within the incubator) which affected the rate of drying, it is difficult to conclude which exact parameter (temperature or rate of drying) was the main factor in determining level of efficacy. It is interesting to note that one of the drying conditions (drying oven at $40^{\circ} \mathrm{C}$ ) that resulted in the most seed transmission of BFB in untreated seed also appeared to be a good drying condition for efficacy of PA. Although drying conditions did not appear to have much effect on efficacy of PA, the $40^{\circ} \mathrm{C}$ drying oven treatment was the only one that had no seed transmission in either test in Table 4. The reason for this apparent paradox is unknown, but perhaps the temperature at which PA is most active is also the drying condition most favorable for bacterial survival on the untreated seed.

Fermentation and $\mathrm{HCl}$ treatments, while effective in eliminating seed transmission to watermelon seedlings, can adversely affect seed quality. This is especially a problem with triploid seed. Efficacious dosages of PA can be applied safely to freshly harvested triploid watermelon seed without concerns for reduction in seed quality.

Our results indicate that PA-based disinfectants can be used to control seed transmission of BFB and other seedborne diseases of cucurbits. An effective wet seed treatment protocol included a 30-min treatment with PA at $1,600 \mu \mathrm{g} / \mathrm{ml}$ followed by 
seed drying at low humidity in a $40^{\circ} \mathrm{C}$ drying oven for $48 \mathrm{~h}$. PA disinfectant could become an important tool in the management of seedborne BFB by the watermelon industry.

\section{LITERATURE CITED}

1. Bauldry, M. G. C. 1983. The bactericidal, fungicidal, and sporicidal properties of hydrogen peroxide and peracetic acid. J. Appl. Bacteriol. 54:417-423.

2. Frankle, W. G. 1992. Bacterial fruit blotch of watermelon: The relationship of the causal bacterium to the fruit and the development of a diagnostic medium. M.S. thesis, University of Florida, Gainesville.

3. Hopkins, D. L. 1991. Chemical control of bacterial fruit blotch of watermelon. Proc. Fla. State Hortic. Soc. 104:270-272.

4. Hopkins, D. L. 1993. Field spread of bacterial fruit blotch of watermelon. (Abstr.) Phytopathology 83:466.

5. Hopkins, D. L., Cucuzza, J. D., and Watterson, J. C. 1996. Wet seed treatments for the control of bacterial fruit blotch of watermelon. Plant Dis. 80:529-532.

6. Hopkins, D. L., and Thompson, C. M. 2002. Seed transmission of Acidovorax avenae subsp. citrulli in cucurbits. HortScience 37:924-926.

7. Hopkins, D. L., Thompson, C. M., and Elmstrom, G. W. 1993. Resistance of watermelon seedlings and fruit to the fruit blotch bacterium. HortScience 28:122-123.

8. Kucharek, T., Perez, Y., and Hodge, C. 1993. Transmission of the watermelon fruit blotch bacterium from infested seed to seedlings. (Abstr.) Phytopathology 83:466.

9. Latin, R. X. 1996. Bacterial fruit blotch. Pages 34-35 in: Compendium of Cucurbit Diseases. T. A. Zitter, D. L. Hopkins, and C. E. Thomas, eds. American Phytopathological Society Press, St. Paul, MN.

10. Latin, R. X., and Hopkins, D. L. 1995. Bacterial fruit blotch of watermelon: The hypothetical exam question becomes reality. Plant Dis. 79:761-765.

11. Latin, R. X., and Rane, K. K. 1990. Bacterial fruit blotch of watermelon in Indiana. Plant
Dis. 74:331.

12. Latin, R. X., Tikhonova, I., and Rane, K. K 1995. Factors affecting the survival and spread of Acidovorax avenae subsp. citrulli in watermelon transplant production facilities. Phytopathology 85:1413-1417.

13. Maynard, D. N., and Hopkins, D. L. 1999 Watermelon fruit disorders. HortTechnology 9:155-161.

14. Rane, K. K., and Latin, R. X. 1992. Bacterial fruit blotch of watermelon: Association of the pathogen with seed. Plant Dis. 76:509-512.

15. Somodi, G. C., Jones, J. B., Hopkins, D. L., Stall, R. E., Kucharek, T. A., Hodge, N. C., and Watterson, J. C. 1991. Occurrence of a bacterial watermelon fruit blotch in Florida. Plant Dis. 75:1053-1056.

16. Walcott, R. R., and Gitaitis, R. D. 2000. Detection of Acidovorax avenae subsp. citrulli in watermelon seed using immunomagnetic separation and the polymerase chain reaction. Plant Dis. 84:470-474.

17. Webb, R. E., and Goth, R. W. 1965. A seedborne bacterium isolated from watermelon. Plant Dis. Rep. 49:818-821. 